AKSARA: Jurnal Ilmu Pendidikan Nonformal

P-ISSN 2407-8018 E-ISSN 2721-7310 DOI prefix $\underline{10.37905}$

Volume 08, (1), January 2022

http://ejurnal.pps.ung.ac.id/index.php/Aksara

\title{
Pembentukan Destinasi Agrowisata Rempah Di Sekitar Air Terjun Tumburano Kabupaten Konawe Kepulauan
}

\author{
Hasniah $^{1}$, Wa Ode Sifatu, ${ }^{2}$ Hartini $^{3}$, Wa Ode Winesty Sofyani ${ }^{4}$, Muh. Danil ${ }^{5}$.
}

1. Anthropology Department, Halu Oleo University. Kampus Hijau Bumi Tridharma, Anduonohu, Kambu, Kota Kendari, Sulawesi Tenggara 93232 Home Adress: BTN Kendari Permai Blok P1 No. 19 Anduonohu, Kendari, 93231. email: hasniahantro67@gmail.com

2. Anthropology Department, Halu Oleo University. Kampus Hijau Bumi Tridharma, Anduonohu, Kambu, Kota Kendari, Sulawesi Tenggara 93232 Home Adress: BTN Unhalu Blok W No. 28 Anduonohu, Kendari, 93232. email: sifawaode@yahoo.co.id, Telp: 081341762438. info@uho.ac.id; waode.sifatu@uho.ac.id.

3. Anthropology Department, Halu Oleo University. Kampus Hijau Bumi Tridharma, Anduonohu, Kambu, Kota Kendari, Sulawesi Tenggara 93232 Home Adress: BTN Puri Tawang Alung Blok C No. 3. Kelurahan Padaleu, Kendari. 93231 email: hartiniuho@gmail.com.

4. Anthropology Department, Halu Oleo University. Kampus Hijau Bumi Tridharma, Anduonohu, Kambu, Kota Kendari, Sulawesi Tenggara 93232 Home Adress: Jln. Haji Daud No. 9 Wua-wua, Kendari, 93117. email: waodewinesty@gmail.com

5. Anthropology Department, Halu Oleo University. Kampus Hijau Bumi Tridharma, Anduonohu, Kambu, Kota Kendari, Sulawesi Tenggara 93232 Home Adress: Jurusan Antropologi Universitas Halu Oleh, Kendari, 93232. email: wulani1018@ gmail.com

Korespondensi:

Wa Ode Sifatu, Jurusan Antropologi, Fakultas Ilmu Budaya, Universitas Halu Oleo; Home Adrss: BTN UNHALU BLOK W, Nomor 28 Kendari, Kode Pos: 93232, Sulawesi Tenggara, Indonesia. Telp:+6281341762438, E-mail: sifatuwaode@gmail.com \& sifawaode@yahoo.co.id

Received: 13 August 2021; Revised: 02 October 2021; Accepted: 28 December 2021 DOI: http://dx.doi.org/10.37905/aksara.8.1.569-580.2022

\begin{abstract}
Air Terjun Tumburano setinggi 98,8 meter hingga saat ini belum dikelola dengan baik. Tujuan untuk mencerahkan masyarakat tentang pentingnya penanaman dan penataan pohon rempah secara artistik di sekitar Air Terjun Tumburano. Metode penyuluhan terhadap 20 orang warga desa (kepala desa dan perangkatnya, anggota kelompok tani, dan ibu-ibu PKK). Hasilnya menunjukkan adanya transfer pengetahuan baru bagi peserta mengenai pohon rempah sebagai tanaman leluhur di kebun pribadi, berubah menjadi tanaman yang menarik di lahan pemerintah sebagai milik semua warga di sekitarnya, sehingga harus dikelola dengan baik agar lestari dan berkelanjutan. Pemerintah segera membuat kerjasama dengan perguruan tinggi dan pengusaha dalam pengelolaan destinasi wisata ini serta segera menyiapkan insfrastruktur jalan, penyediaan bibit tanaman rempah dan ruang terbuka hijau (RTH) di sekitarnya. Penyuluhan ini dapat ditindaklanjuti dengan jenis pengabdian lain seperti: pelatihan mengolah bahan-bahan lokal yang bisa dinikamti di Air Terjun Tumburano dan menjadi ole-ole, serta pembuatan souvenir khas Kabupaten Konawe Kepulauan.
\end{abstract}

Kata-kata kunci: agrowisata rempah, Air Terjun Tumburano, ole-ole. 


\section{PENDAHULUAN}

Pola pembangunan di Desa Tumburano belum menerapkan UU No. 6 Tahun 2014, selain karena ketidakpahaman warganya yang terbukti dengan aktivitas sejumlah remaja tertentu (dari kaum elit) menagih retribusi dengan tarif tidak tetap dari wisatawan di sekitar Air Terjun Tumburano, juga perencanaannya belum melibatkan seluruh lapisan masyarakat. Desa Tumburano memiliki luas wilayah 5.700 M2., dimana Air Terjun Tumburano Tina dan Tumburano Tama berada setinggi 98,8 meter, yang saat ini sangat diminati oleh kaum milenial pencinta alam. Melindungi kelestarian mata Air Terjun Tumburano, pemerintah Kabupaten Konawe Kepulauan telah menetapkan hutan lindung dari Desa Tumburano seluas $20 \mathrm{Ha}$, namun terkesan gersang karena hutan tersebut masih menjadi tempat warga mengambil kayu untuk bahan bangunan rumah dan pembuatan perahu. Desa Tumburano memiliki jumlah penduduk sebanyak 261 jiwa dengan 70 Kepala Keluarga (KK).

Potensi dan peluang usaha jasa pengembangan Destinasi Agrowisata di Ait Terjun Tumburano didukung oleh adanya Sekolah Menengah Atas (SMA) Negeri 1 Konawe Kepulauan, terdapat Kantor Polsek Kecamatan Wawonii Utara, terdapat tanah kosong di samping Kantor Polsek yang juga berpotensi dibangun kolam renang dengan mengambil air bersih dari air terjun Tumburano, dan di sekitar Pelabuhan Perahu Nelayan Desa Tumburano terdapat hutan bakau seluas sekitar $20 \mathrm{Ha}$.

Kegiatan penyuluhan yang telah diselenggarakan pada tanggal $9-10$ September 2021 diawali dengan kunjungan bersama tim penyuluh dan aparat pemerintah desa ke Air Terjun Tumburano dilanjutkan di Balai Desa Tumburano yang diikuti oleh 20 orang peserta yang terdiri atas aparat pemerintah desa, Kelompok Tani, dan ibu-ibu PKK. Melalui penyuluhan ini terungkap bahwa Anggota Kelompok Tani dengan bertani sawah tampak semrawut dengan memanfaatkan sumber Air Terjun Tumburano karena diarahkan oleh pemerintah, sesungguhnya bukan warisan leluhur mereka. Kecuali bertanam pohon rempah telah diturunkan dari generasi ke generasi.

\section{Masalah}

Berdasarkan uraian analisis situasi, maka permasalahan prioritas mitra yang melatarbelakangi kegiatan penyuluhan ini antara lain sebagai berikut.

a. Kurangnya pengetahuan masyarakat tentang pengelolaan dan pemanfaatan hutan yang terkenan gersang di sekitar Air Terjun Tumburano.

b. Rendahnya pengetahuan anggota kelompok tani mengenai teknologi penataan pohon rempah-rempah agar menarik dipandang mata.

c. Kurangnya informasi pemasaran Destinasi Pariwisata Air Terjun Tumburano, sehingga potensi ekonomi dari retribusinya hanya dinikmati oleh remaja elit tanpa tarif yang tetap.

\section{Tujuan}

Tujuan penyelenggaraan penyuluhan yang dilakukan di Desa Tumburano sebagai berikut.

a. Meningkatkan pengetahuan masyarakat tentang kepemilikan dan pemanfaatan hutan di sekitar Air Terjun Tumburano.

b. Meningkatkan pengetahuan masyarakat mengenai teknologi penataan pohon rempah-rempah agar menarik dipandang mata di sekitar Air Terjun Tumburano. 
c. Meningkatkan pengetahuan masyarakat mengenai pemasaran Destinasi Pariwisata Air Terjun Tumburano, sehingga potensi ekonomi dapat dinikmati oleh seluruh warga masyarakat dengan tarif retribusi yang tetap.

d. Terwujudnya Air Terjun Tumburano menjadi destinasi agrowisata rempah di Sulawesi Tenggara.

\section{Review Pustaka}

Kabupaten Konawe kepulauan merupakan salah satu kabupaten dari 17 kabupaten dan dua kota di Sulawesi Tenggara. Kabupaten tersebut resmi berdiri sebagaimana Sejarah Kabupaten Konawe Kepulauan, 2017). Untuk meningkatkan peran masyarakat dalam pembangunana desa di gunakan metode PAR.

PAR menawarkan alternatif radikal untuk pengembangan pengetahuan sebagai penyelidikan kolektif, refleksi diri untuk tujuan memperbaiki situasi dalam komunitas atau dalam kelompok individu yang terpinggirkan (Koch, T., Selin, P. \& Kralik, 2002); Maguire (1987). Dalam sejarah dan perkembangan Participatory Action Research (PAR), Terdapat banyak ahli pendidikan, ahli ilmu sosial humaniora, kesehatan, dan antroplogi yang telah melaporkan sejarah dan perkembangan (McTaggart, 2007) PAR.. PAR memberdayakan, karena mempromosikan pengembangan kapasitas dan pembangunan kapasitas di semua yang berpartisipasi (Mc Taggart, et al, 1989, 1991, 1997 ). PAR telah dikutip sebagai proses pendidikan, pendekatan investigasi sosial, dan cara untuk mengambil tindakan untuk mengatasi masalah dan isu-isu dalam komunitas dan dalam kelompok individu Mereka memberikan contoh, Vincent Crapanzano - El Dilema de Hermes, September 1994.), di Apache, Oklahoma, saya duduk dengan sesepuh Kiowa dan penyanyi Ralph Kotay di meja dapurnya, menyeruput Ralph mengingatkan saya akan peran lagu Kiowa dalam hidupnya: "Saya selalu berterima kasih kepada Maha Kuasa telah memberi saya sesuatu yang bisa saya nikmati, "katanya. "Sampai hari ini, saya senang bernyanyi. Saya bernyanyi untuk membantu keluarga dan teman-teman. . . . Itu selalu bagus. Ini hidupku - nyanyianku. "Setelah beberapa menit Ralph tiba-tiba mengubah taktiknya, berbicara terus terang tentang pekerjaannya dengan saya: "Saya selalu bersedia memberikan informasi seperti ini. Tapi. . . Saya tidak ingin ada yang dikatakan di atas ini. Beberapa orang yang menulis buku, saya telah membaca cerita mereka di mana mereka membangun hal-hal yang sebenarnya tidak ada. Ketika orang tidak tahu [lebih baik], kapan pun mereka mendengar hal-hal ini, mereka percaya apa yang Anda katakan atau tulis. "2 tentang kekuasaan dan politik representasi. Di sini Ralph Kotay mengangkat masalah yang banyak ditemui oleh para etnografer dalam berbagai bentuk dalam percakapan mereka dengan kolaborator etnografis mereka: yaitu, kesenjangan antara narasi yang ditempatkan secara akademis dan yang diposisikan dalam komunitas. Pada dasarnya, perhatian Kotay adalah tentang kekuasaan dan politik representasi; tentang siapa yang berhak mewakili siapa dan untuk tujuan apa, dan tentang wacana siapa yang diistimewakan dalam teks etnografi. Kobsep partisipasi dalam artikel ini mengacu pemikiran Mubyarto (1997) menyatakan bahwa kesediaan setiap orang sebagai anggota masyarakat untuk berperanserta dalam membantu untuk keberhasilan setiap program sesuai kapasitasnya tanpa mengorbankan kepentingan diri sendirti.

Menelusuri hasil kajian mengenai program penanganan masyarakat di Indonesia, terdapat sejumlah kajian, diantaranya hasil penelitian yang dilakukan oleh Fiantis (1967), bahwa anggota masyarakat berperanserta dalam pembangunan sanga menentukan 
keberhasilan suatu rencana pembangunan. Menurut Elida Imro'atin dkk. (2015), partisipasi masyarakat dalam pembangunan sangat penting karena dapat menumbuhsuburkan rasa memiliki dan mempertinggi rasa tanggung jawab mulai dari proses perencanaan, pelaksanaan, dan evaluasi pembangunan. Menurut Andreeyan (2014), keterlibatan seluruh anggota masyarakat dapat berarti sebagai peranserta masyarakat dalam setiap program pembangunan. Rizal A., juga juga menyampaikan bahwa peningkatan partisipasi masyarakat merupakan salah satu bentuk pemberdayaan sosial aktif yang berorientasi pada pencapaian hasil pembangunan yang dilakukan di masyarakat pedesaan. Pemberdayaan masyarakat adalah upaya untuk menggunakan dan mengelola sumberdaya masyarakat pedesaan secara lebih aktif dan efisien. Herman (2019), menjelaskan bahwa proses persiapan secara sistematis seluruh kegiatan pembangunan merupakan sebuah proses perencanan pembangunan. Seluruh proses pengambilan keputusan berdasarkan fakta di lapangan, akan menjadi acuan yang baik dalam proses pembangunan dan akan menghasilkan manfaat yang baik.

Menurut UU No. 6 Tahun 2014 Tentang Desa, bahwa desa adalah kesatuan masyarakat hukum yang memiliki batas wilayah yang berwenang untuk mengatur dan mengurus urusan pemerintahan, kepentingan masyarakat setempat berdasarkan prakarsa masyarakat, hak asal usul, dan atau hak tradisional yang diakui dan dihormati dalam sistem pemerintahan negara. Negara Kesatuan Republik Indonesia. Untuk mendapatkan dukungan dan partisipasi yang kuat dari masyarakat untuk pembangunan desa, masyarakat harus dilibatkan dalam proses pengambilan keputusan, termasuk pada tahap perencanaan pembangunan desa. Dengan demikian diharapkan ada rasa tanggung jawab bersama seluruh masyarakat desa terhadap pembangunan di desanya.

Susetiawan, dkk. (2018), menjelaskan upaya berpartisipasi dalam pembangunan masyarakat perlu memiliki pemahaman yang luas tentang pembangunan partisipatif, terutama dalam aspek perencanaan. Pemahaman masyarakat tentang partisipasi dalam perencanaan sangat diperlukan dalam pembangunan partisipatif karena pemahaman perencanaan dalam pembangunan partisipatif akan meningkatkan kesadaran masyarakat akan pentingnya partisipasi masyarakat. Fadil (2013), menjelaskan bahwa jika masyarakat memahami suatu program pembangunan sejak awal perancangannya, dapat meningkatkan kesadaran seluruh anggota masyarakat dan dapat berperan serta dengan baik.

Pernyataan Fadil di atas sejalan dengan rancangan pariwisata rempah di Air Terjun Tumburano di Desa Tumburano yaitu: pala, cengkeh, kayu manis, kelapa, lada, dan tanaman obat. Pariwisata rempah di Desa Tumburano akan berbeda dengan rancangan destinasi agrowisata rempah di Solok, yang menjadi binaan Balai Penelitian Tanaman Rempah dan Obat (Balittro) di Sumtera Barat yang ditetapkan sejak tanggal 5 Desember 2018. Juga berbeda dengan Agrowisata Lada, 2017a; Agrowisata Lada, 2017b) Pariwisata rempah Solok dengan mendesign taman herbal untuk edukasi masyarakat agar lebih mengenal tanaman obat asli Indonesia oleh Malvyandie Haryadi, mengenai destinasi agrowisata di Bangka Belitung oleh media Tribunnews.Com, Bangka Pos. Tanaman lada milik Badan Pengelola, Pengembangan dan Pemasaran Lada (BP3L) Babel di Desa Cambai, Kabupaten Bangka Tengah, pada tanggal 16-2-2017. Demikian pula yang dilaporkan oleh Wartawan Bangka Pos, Iwan Setiawan. Namun pengembangan Agrowisata di Air Terujun Tumburano di Desa Tumburano akan menemukan hambatan yang cukup berarti karena hanya masyarakat desa yang berharap bantuan dari luar karena 
menganggap Pemda Kabupaten Konawe Kepulauan relatif kurang menerima saran sebagaimana penyampaian kepala desa kepada para pemateri penyuluhan. Akibatnya, kepala desa belum bersedia mengantar para penyuluh ke Pemerintah Daerah Konawe Kepulauan untuk pengembangannya dalam pola kerja sama antara perguruan tinggi, pemerintah daerah, dan pengusaha.

\section{Metode}

Metode pelaksanaan dalam kegiatan pepenyuluhan ini adalah Tim penyuluh bersama Aparat Desa dipimpin Kepala Desa Tumburano turun lapangan dalam hal ini di Air Terjun Tumburano untuk menunjukkan hal-hal yang perlu dilakukan di lapangan. Setelah itu, tim penyuluh dan aparat desa dan kepala Desa bersama-sama ke Balai Desa Tumburano untuk berdiskusi tentang pengembangan Destinasi Agrowisata Rempah di Air Terjun Tumburano. Dalam pertemuan di Balai Desa Tumburano telah diikuti anggota Kelompok Tani, anggota PKK dan semua warga yang hadir, selengkapnya sebagai berikut.

\subsection{Mekanisme Pelaksanaan}

Metode yang telah dipakai dalam pencapaian tujuan tersebut adalah Participatory Action Research (PAR) merupakan metode pemberdayaan masyarakat dalam pembangunan kewilayahan dan dengan prosedur kerja melalui pendekatan memanfaatkan teknologi. PAR mendapatkan popularitas di sejumlah disiplin ilmu, terutama pendidikan, kesehatan, pengembangan masyarakat, pertanian, dan pekerjaan sosial (lihat: Gillis \& Jackson, 2002; Koch, Selim, \& Kralik (2002); Maguira (1987); MacTaggar (1989; 1997); Koch, T., et all. (2002).

Mekanisem pelaksanaan PAR menawarkan alternatif radikal untuk pengembangan pengetahuan sebagai penyelidikan kolektif, refleksi diri untuk tujuan memperbaiki situasi dalam komunitas atau dalam kelompok individu yang terpinggirkan (Koch, Selim, \& Kralik, 2002; Maguira 1987). Meskipun ada beberapa tantangan dalam melakukan penelitian PAR, ini adalah metodologi penelitian yang berharga untuk dipertimbangkan oleh setiap peneliti yang ingin mengambil tindakan dan membuat perubahan. Materi yang dibutuhkan dalam kegiatan adalah sebagai berikut.

\subsection{Materi Kegiatan}

1) Penyuluhan teknik penataan agrowisata rempah seperti pohon pala, cengkeh, kayu manis, dan merica, dari tim pengabdian.

2) Pentingnya pengadaan berbagai fasilitas di lokasi Air Terjun Tumburano untuk menarik minat pengunjung.

\section{HASIL DAN PEMBAHASAN}

Sepanjang waktu dua bulan pelaksanaan kegiatan penyuluhan ini berakhir tangga 10 September 2021, tim penyuluh bersama masyarakat Desa Tumburano merancang Agrowisata rempah di Air Terjun Tumburano. Kegiatan penyuluhan, jelas tampak pada tabel 1. Narasumber dalam penyuluhan ini adalah Dr. Wa Ode Sifatu, M.Si., Dr. Wa Ode Winesty Sofyani, M.A., Dra. Hasniah, M.Si., dan Hartini, S.Sos.,M.Si.

Tabel 1. Kegiatan penyuluhan tentang penanaman dan penataan Agrowisata rempah di Air Terjun Tumburano. 


\begin{tabular}{|l|l|l|l|}
\hline No. & Uraian & Peserta & Waktu keg. \\
\hline 1. & $\begin{array}{l}\text { Kunjungan lapangan ke Air Terjun } \\
\text { Tumburano. }\end{array}$ & $\begin{array}{l}\text { a. Kepala Desa } \\
\text { b.Perangkat Desa } \\
\text { c. Tim Penyuluh }\end{array}$ & 8-9-2021 \\
\hline 2. & $\begin{array}{l}\text { Penyuluhan teknik penataan } \\
\text { agrowisata rempah seperti pohon pala, } \\
\text { cengkeh, kayu manis, kelapa dan } \\
\text { merica, serta pentingnya pengadaan } \\
\text { fasilitas pendukungnya di lokasi Air } \\
\text { berangkat Desa } \\
\text { c. Kelompok Tani } \\
\text { d. Ibu-Ibu PKK } \\
\text { Desa Tumburano. } \\
\text { minat pengunjung dari tim pengabdian } \\
\text { di Balai Desa Tumburano. }\end{array}$ & 9-9-2021 \\
\hline 3. & $\begin{array}{l}\text { Kepala Desa bersama perangkat desa } \\
\text { mengantar Tim mengunjungi kebun } \\
\text { warga untuk memperlihatkan jenis } \\
\text { pohon tumbuhan rempah yang ditanam } \\
\text { masyarakat selama ini. }\end{array}$ & $\begin{array}{l}\text { a. Kepala Desa } \\
\text { b.Perangkat Desa } \\
\text { c. Kelompok Tani } \\
\text { d. Ibu-Ibu PKK Desa } \\
\text { Tumburano.. }\end{array}$ & \\
\hline
\end{tabular}

Sumber: Data lapangan diolah, Desa Tumburano, 2021

\subsection{Proses Pengabdian}

Tim penyuluhan melakukan persiapan jauh hari sebelum jadwal yang ditetapkan untuk melakukan penyuluhan. Hal ini dilakukan agar dapat diperoleh hasil yang maksimal sesuai dengan tahapan yang telah ditetapkan dan telah diuraikan pada bagian sebelumnya di atas. Tahapan ini antara lain, persiapan administrasi sesuai persyaratan yang telah ditetapkan oleh LPPM UHO, koordinasi dengan kepala desa setempat, dan persiapan-persiapan tim seperti materi penyuluhan.

Tahapan kedua yang dilakukan oleh tim adalah observasi di lingkungan dimana akan dilaksanakan penyuluhan. Observasi ini dilakukan dengan maksud untuk melihat secara langsung permasalahan di lapangan terkait dengan topik penyuluhan mengenai "Pengembangan jasa destinasi pariwisata Air Terjun Tumburano menjadi destinasi wisata rempah di Sulawesi Tenggara". Dengan observasi ini, maka tim memperoleh gambaran yang komprehensip mengenai permasalahan Air Terjun Tumburano sehingga belum menjadi tujuan wisata yang belum menarik.

Tahapan terakhir untuk lapangan, yakni kegiatan pengabdian berupa penyuluhan yang dilakukan di Balai Desa Tumburano yang dihadiri oleh 20 (dua puluh) orang warga yang terdiri dari aparat desa, kelompok tani, dan ibu PKK. Proses pengabdian dalam bentuk penyuluhan ini, dibagi atas tiga sesi, yakni: pertama, sesi pemaparan materi penyuluhan yang dilakukan oleh narasumber dari tim penyuluh, sesi kedua diskusi sekaligus tanya jawab antara tim penyuluh dengan peserta, dan sesi ketiga adalah penyamaan persepsi antara tim penyuluh dengan peserta dalam hal ini masyarakat setempat.

1. Sesi pemaparan materi penyuluhan tentang tujuan orang berwisata. Adapun tujuan orang berwisata adalah mencari kesenangan, kebahagian, menghindari penderitaan, juga membelanjakan uangnya untuk membeli produk khas lokal untuk dibawa pulang ke tempat asalnya dan dibagikan kepada tetangga dan handai taulan terutama kaum muda. Oleh karena itu, destinasi wisata harus dibuat semenarik mungkin dan 
menyenangkan bagi setiap pengunjung. Mengingat kondisi Air Terjun Tumburano yang sangat indah, namun belum didukung oleh prasarana transportasi, belum ditumbuhi oleh tumbuhan rempah seperti yang tumbuh di kebun masyarakat yang ada di sekitar lokasi air terjun dan bahkan di seluruh wilayah kabupaten di Konawe Kepulauan. Selain itu, hutan yang rusak karena ulah manusia yaitu pelaku illegal loging, menyebabkan hutan di sekitarnya rusak dan belum dilakukan penghijauan kembali. Menurut tim penyuluh, akan lebih bagus jika dilakukan penghijauan kembali dengan menanam pohon rempah sehingga menjadi milik bersama seluruh warga, dalam bentuk destinasi wisata rempah.

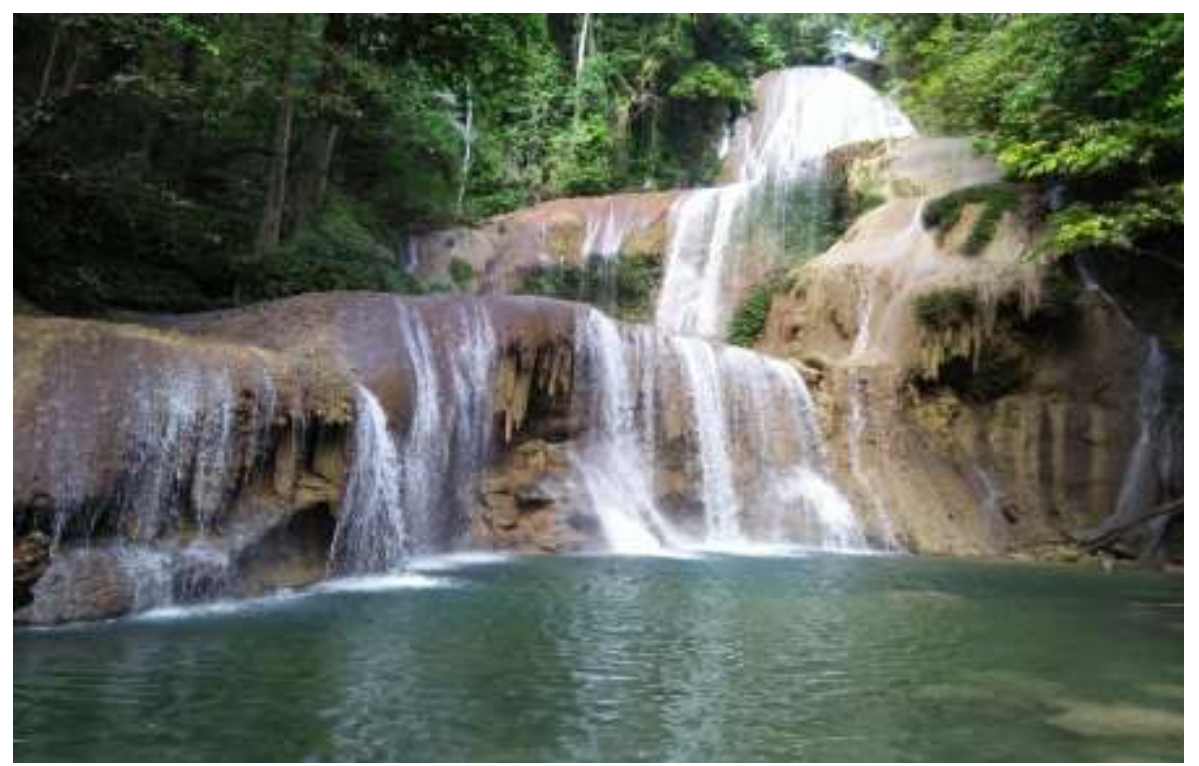

Foto 1. Air Terjun Tumburano Tina (Perempuan)

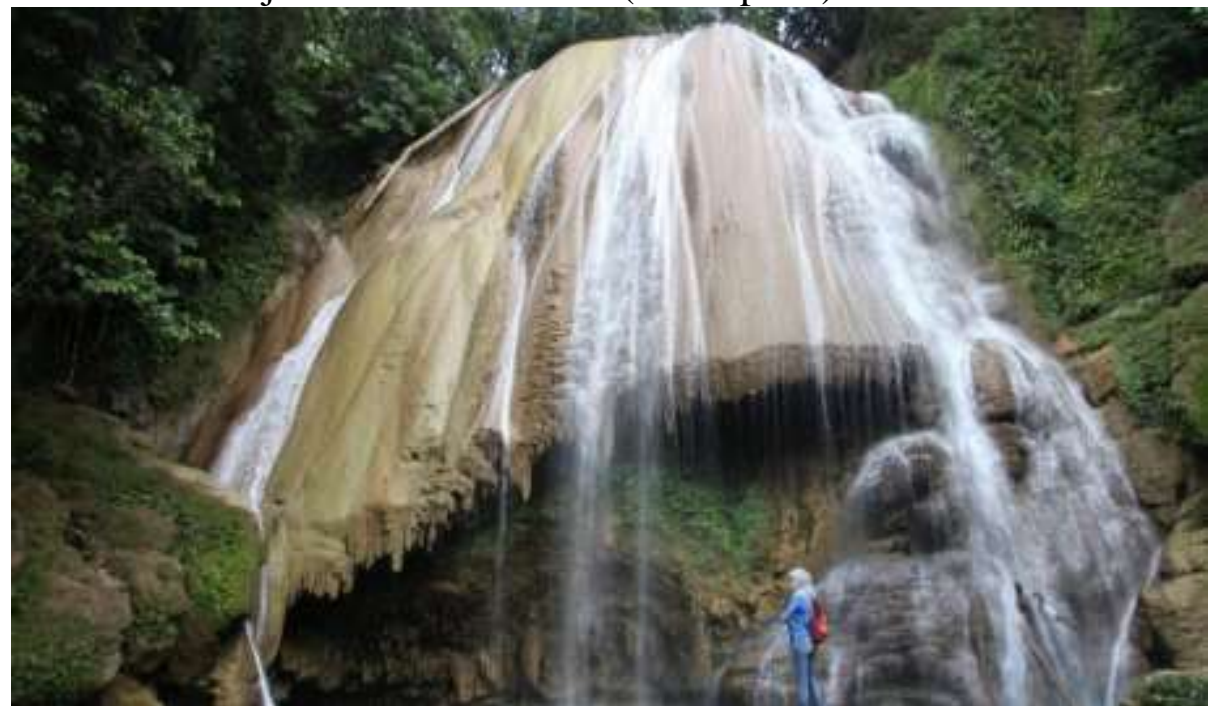

Foto 2. Air Terjun Tumburano Tama (Laki-laki)

2. Sesi diskusi atau tanya jawab

Setelah berakhirnya pemaparan materi oleh tim penyuluh, maka dilanjutkan dengan sesi diskusi atau tanya jawab antara tim penyuluh dengan peserta terkait keberadaan 
Air Terjun Tumburano dan lingkungan sekitarnya. Sesi diskusi ini langsung dipandu oleh salah seorang tim penyuluh dengan focus pertanyaan sebagai berikut.

- Kenapa warga dianjurkan menanam pohon rempah di sekitar air terjun padahal itu adalah lahan milik pemerintah?

- Siapa yang akan merawatnya?

- Siapa yang akan memanennya?

- Kenapa bukan pemerintah saja yang menanam?

- Untuk apa pohon rempah ditanam di sekitar air terjun?

- Siapa sebenarnya yang berhak mengelola air terjun ini, karena selama ini remaja dari desa inilah yang memungut retribusi dari pengunjung dengan tarif yang tidak tetap?

Semua pertanyaan dari peserta, dijawab oleh tim penyuluh yang diperkuat dengan penjelasan dari Kepala Desa Tumburano.

Adapun hasil yang diperoleh dari kegiatan pengabdian ini adalah sebagai berikut:

1. Warga masyarakat sangat antusias dalam mengikuti kegiatan pengabdian berupa penyuluhan ini, baik saat mendengarkan materi, maupun pada saat sesi diskusi atau tanya jawab.

2. Pertanyaan-pertanyaan yang diajukan oleh peserta terkait pengelolaan Air Terjun Tumburano, sifatnya adalah menambah pengetahuan mereka tentang cara pengelolaan destinasi wisata yang nyaman dan menyenangkan bagi pengunjung sehingga mau berkunjung lagi dan mengajak orang lain menjadi pengunjung.

3. Peserta penyuluhan mengakui bahwa mereka mendapatkan pengetahuan baru tentang pengunjung wisata.

4. Setelah berdiskusi dengan pemateri, mereka mengaku bahwa selama ini mereka tidak memperhatikan air terjun ini.

5. Warga baru menyadari bahwa Air Terjun Tumburano adalah sumberdaya milik bersama yang sangat berharga sehingga perlu dijaga secara bersama kelestarian dan keberlanjutannya.

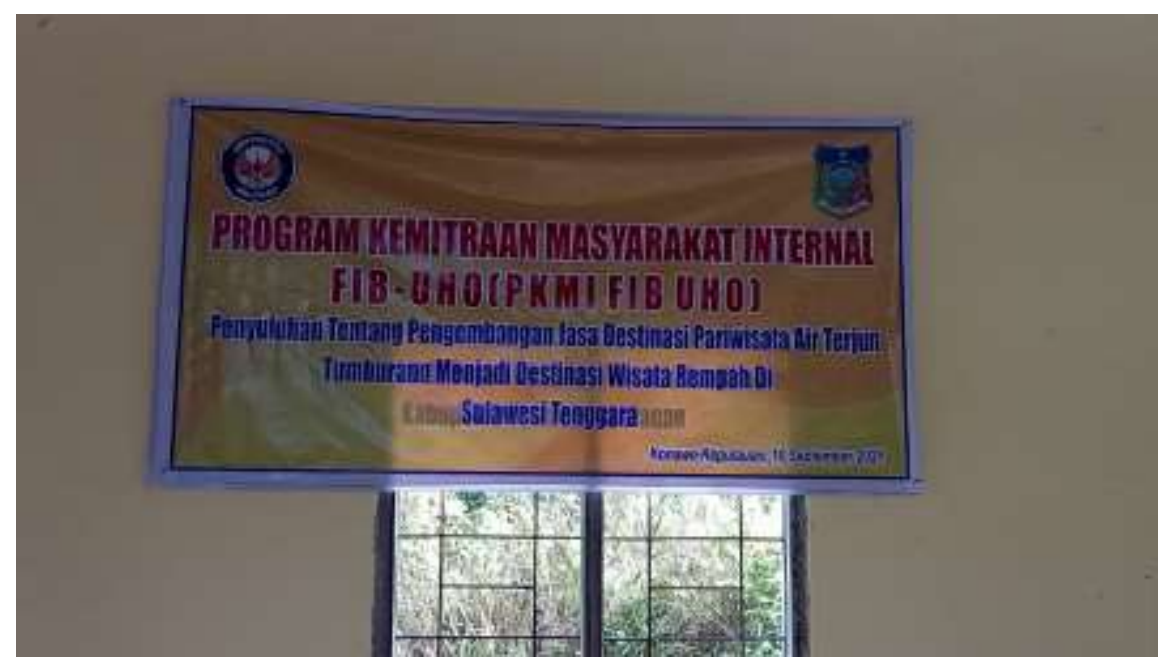

Foto 3. Spanduk Kegiatan Pengabdian 


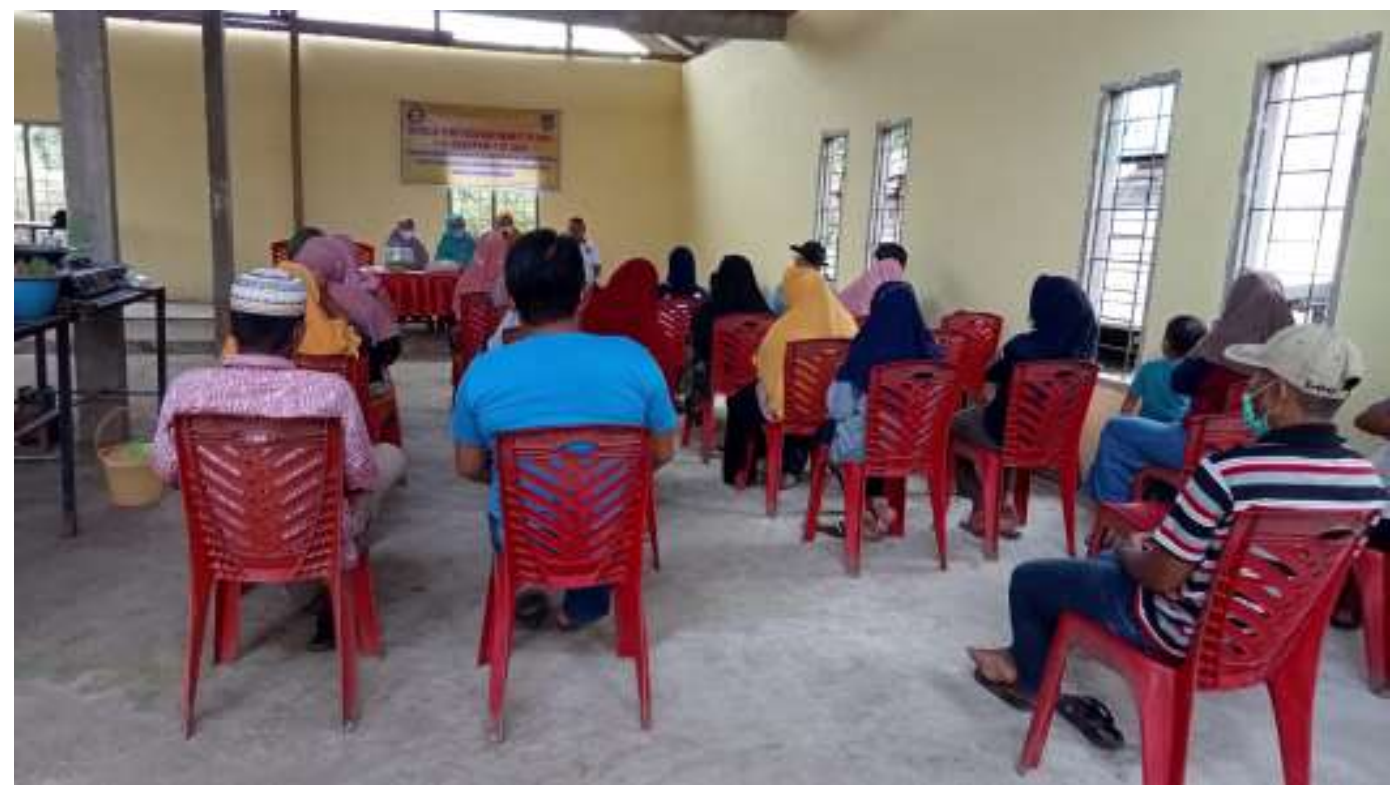

Foto 4. Kegiatan Penyuluhan di Balai Desa Tumburano

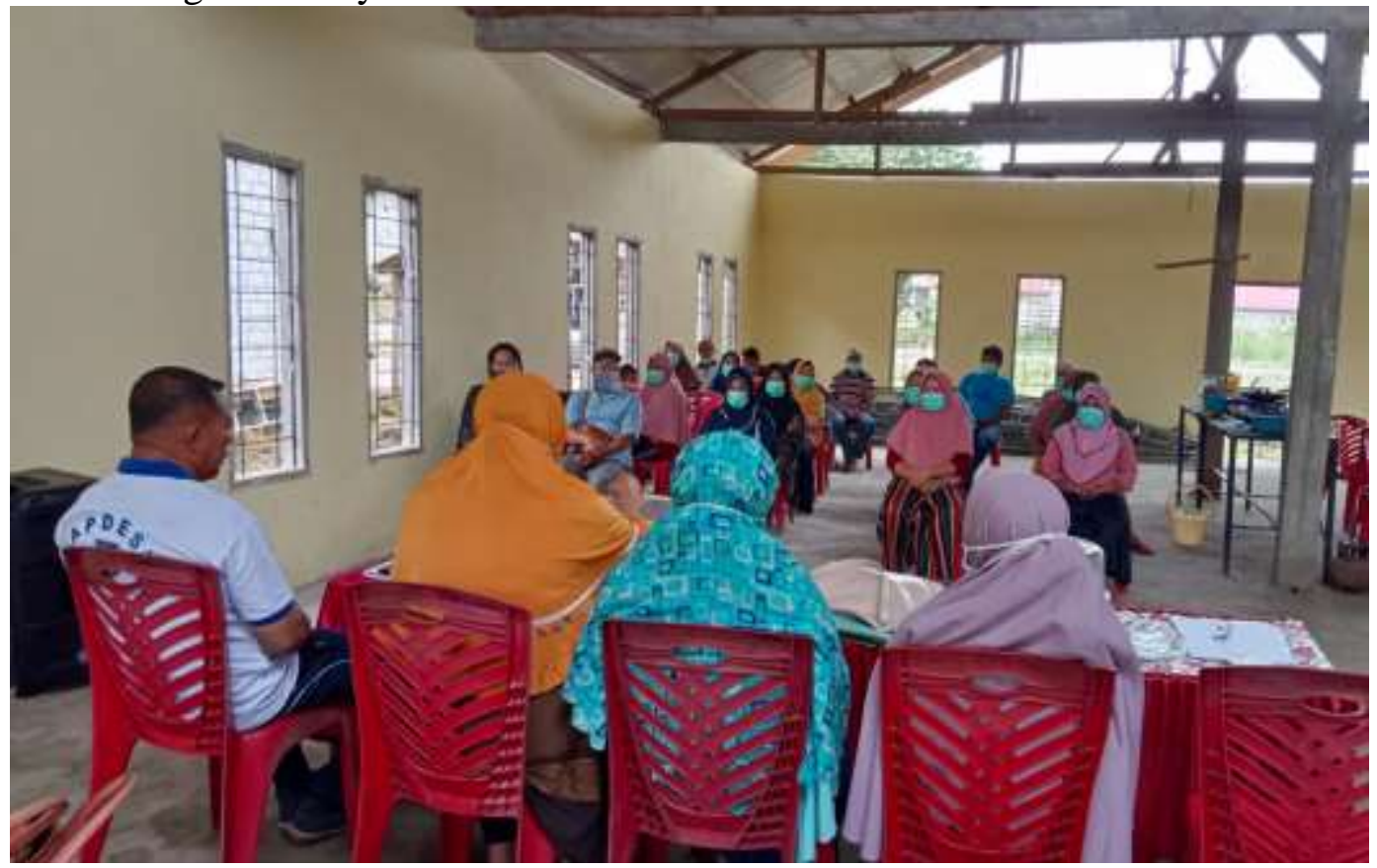

Foto 5. Pemaparan Materi Penyuluhan

\subsection{Materi Penyuluhan}

1. Rempah merupakan salah satu daya tarik yang menyebabkan orang Eropah datang ke Indonesia

2. Tumbuhan rempah yang terlengkap di Indonesia ada di Kabupaten Konawe Kepulauan (lada, cengkeh, pala, kayu manis, dan kelapa)

3. Penataan tumbuhan rempah harus artistik

4. Disediakan Ruang Terbuka Hijau (RTH)

5. Perlu fasilitas MCK

6. Perlu fasilitas gazebo yang cukup 
7. Perlu fasilitas warung makan yang dilengkapi dengan souvenir khas lokal Kabupaten Konawe Kepulauan

\subsection{Hasil yang Dicapai}

Adapun luaran yang dihasilkan melalui kegiatan pengabdian ini adalah adanya berita kegiatan pengabdian yang akan dimuat di Harian Kendari Pos. Selain itu, hasil kegiatan pengabdian ini akan dimuat di jurnal ilmiah nasional yang terakreditasi.

Tabel 2. Hasil Survey Mengenai Kesadaran Untuk Penataan dan Penanaman Pohon Rempah Menjadi Destinasi Agrowisata Rempah di Air Terjun Tumburano.

\begin{tabular}{|l|l|c|c|c|}
\hline No. & \multicolumn{1}{|c|}{ Uraian } & \multirow{2}{*}{ Jumlah } & \multicolumn{2}{c|}{ Hasil Survey } \\
\cline { 3 - 5 } & & & Ya & Tidak \\
\hline 1 & Perangkat Desa & 3 & 3 & - \\
\hline 2 & Kelompok Tani & 8 & 8 & - \\
\hline 3 & Ibu-Ibu PKK di Desa Tumburano & 9 & 9 & - \\
\hline & Total & 20 & 20 & - \\
\hline
\end{tabular}

Data lapangan, diolah, Desa Tumburano, 2021.

Untuk mengukur komitmen peserta penyuluhan mengenai pembentukan Desatinasi Agrowisata Rempah di Air Terjun Tumburano, disusun secara bersama yang melibatkan seluruh warga desa. Hal ini dibuktikan dengan adanya rencana program kegiatan kepada pemerintah Kabupaten Konawe Kepulauan.

\section{KESIMPULAN DAN SARAN \\ Kesimpulan}

Kegiatan pengabdian melalui penyuluhan dengan topik "Pengembangan Jasa Destinasi Pariwisata Air Terjun Tumburano menjadi Destinasi Agrowisata Rempah di Sulawesi Tenggara" ini secara umum telah berlangsung dengan baik, sesuai dengan tujuan yang diharapkan. Respon mitra, baik pemerintah desa maupun warga masyarakat, sangat baik untuk setiap tahapan kegiatan yang dilaksanakan.

Hasil pengabdian ini menunjukkan, destinasi agrowisata rempah terlengkap di Indonesia dapat diwujudkan di lokasi Air Terjun Tumburano, mengingat daerah ini adalah penghasil rempah terbesar dan terlengkap di Sulawesi Tenggara. Optimisme tim penyuluh didasari oleh kenyataan bahwa tanaman rempah telah menjadi budaya masyarakat lokal secara turun temurun, sehingga tidak sulit untuk mewujudkan rencana tersebut.

Melalui kegiatan penyuluhan ini, mitra memperoleh pengetahuan bahwa dengan pengelolaan destinasi wisata yang baik, dapat menjadi sumber ekonomi bagi masyarakat di sekitarnya. Hal itu disebabkan oleh dengan kehadiran wisatawan di sustu destinasi wisata, akan membutuhkan alat transportasi, tempat penginapan, tempat makan, pemandu wisata, dan souvenir. Itu semua bisa dilakukan oleh masyarakat lokal.

\section{Saran}

Bardasarkan hasil yang diperoleh melalui kegiatan pengabdian ini, maka sejumlah rekomendasi sebagai saran dari tim pengabdian adalah sebagai berikut :

1. Saatnya bagi pemerintah daerah Kabupaten Konawe Kepulauan untuk memulai menyiapkan prasarana yang dibutuhkan di Air Terjun Tumburano 
2. Terbukanya destinasi agrowisata rempah di Air Terjun Tumburano, maka masyarakat akan memperoleh keuntungan secara ekonomi dan sosial.

3. Sebaiknya pemerintah Kabupaten Konawe Kepulauan juga harus masif membantu masyarakat mewujudkan destinasi agrowisata rempah di Air Terjun Tumburano.

4. Pemerintah daerah Kabupaten Konawe Kepulauan seharusnya melakukan kerja sama dengan perguruan tinggi dan pengusaha untuk mempercepat terwujudnya cita-cita masyarakat di sekitar Air Terjun Tumburano.

\section{DAFTAR PUSTAKA}

Adisasmita, (2006). “Pembangunan Pedesaan Dan Perkotaan”. Yogyakarta: Graha Ilmu

Destinasi Agrowisata Rempak di Solok, Sumatera Barat. Kegiatan tersebut didukung oleh Balai Penelitian Tanaman Rempah dan Obat (Balitro) Kementerian Pertanian Republik Indonesia, 14 November 2021. Tersedia di https://balittro.litbang.pertanian.go.id/?p=3926 diakses tanggal 14 November 2021, pukul 20.55 WITA.

Fadil, Fathurrahman et al. 2013. "Partisipasi Masyarakat Dalam Musyawarah Perencanaan Pembangunan di Kelurahan Kotabaru Tengah". Dalam Jurnal Ilmu Politik dan Pemerintahan Lokal, Volume II Edisi 2. Pp. 251-261.

Koch, T., Selin, P. \& Kralik, D. (2002). Enhancing lives through the development of a community-based participatory action research program. Jounal of Clinical Nursing, 11, 109-117.

McTaggart, R. (1989). 16 Tenets of Participatory Action Research. Retrieved November 15, 2006 from http://www,caledonia.orguk/par.htm. Diakses 25 Oktober 2020 pukul 20.42 WITA.

McTaggart, R. (1991). Principles for Participatory Action Research. Adult Education Quality, 41 (3). 168-187. Diakses 25 Oktober 2020 pukul 20.45 WITA.

McTaggart, R. (1997). Participatory Action Research. New York: State University of New York Press. Diakses 25 Oktober 2020 pukul 20.50 WITA.

Mubyarto. 1997. "Gerakan Nasional Penanggulangan Kemiskinan, Kajian Bersama Pengembangan Kebijaksanaan”. Yogyakarta: Aditya Media.

Mulvyandie Haryadi (2017). Agrowisata Lada yang hanya ada di Bangka Belitung. Berita tersebut dilaporkan melalui Tribun New.com. dengan link: https://www.tribunnews.com/travel/2016/02/17/agrowisata-lada-destinasi-unikyang-hanya-ada-di-bangka-belitung. Diakses diakses tanggal 14 November 2021, pukul 21.5 WITA. 
Nur Laily, Elida Imro'atin (2015). Partisipasi Masyarakat Dalam Perencanaan Pembangunan Partisipatif'. Jurnal Kebijakan dan Manajemen Publik, volume 3, nomor 2. pp. 186-190.

Pemerintah Kabupaten Konawe Kepulauan 2018. Tersedia di http://konkepkab.go.id/main Diakses tanggal 14-11-2021, pukul 20.13 WITA.

Susetiawan, DC Mulyono, Muhammad Yunan, Roniardian (2018). Penguatan Peran Warga Masyarakat dalam Perencanaan, Penganggaran, dan Evaluasi Hasil Pembangunan Desa. Jurnal Pengabdian Kepada Masyarakat UGM. Vol. 4, Nomor 1, pp. 109-118. 